World Journal of Advanced Research and Reviews
eISSN: 2581-9615 CODEN (USA): WJARAI
Cross Ref DOI: $10.30574 /$ wjarr
Journal homepage: https://wjarr.com/

(CASE REPORT)

Check for updates

\title{
Management and treatment procedure of windpuff caused by lice infestation in domestic pigeon: A case report
}

\author{
Mishuk Shaha 1, Arjuman Lima 1, Ashutosh Das 1, Gous Miah 1, Sabuj Kanti Nath 2, Pranab Paul 3, Towhida \\ Kamal ${ }^{4}$, Ashim Baran Sen ${ }^{5}$ and Omar Faruk Miazi 1,* \\ ${ }^{1}$ Department of Genetics and Animal Breeding, Chittagong Veterinary and Animal Sciences University (CVASU), \\ Chattogram, Bangladesh. \\ 2 Department of Animal Nutrition, Khulna Agricultural University, Bangladesh. \\ ${ }^{3}$ Department of Medicine and Surgery, Chittagong Veterinary and Animal Sciences University (CVASU), Chattogram, \\ Bangladesh. \\ ${ }^{4}$ Department of Pathology and Parasitology, Chittagong Veterinary and Animal Sciences University (CVASU), \\ Chattogram, Bangladesh. \\ 5 Upazila Livestock Officer, Cox's Bazar Sadar.
}

World Journal of Advanced Research and Reviews, 2021, 10(02), 220-224

Publication history: Received on 07 March 2021; revised on 30 April 2021; accepted on 04 May 2021

Article DOI: https://doi.org/10.30574/wjarr.2021.10.2.0151

\begin{abstract}
A rare case of windpuff was diagnosed in 7 months old two domestic pigeons due to itching and scratching with inanimate objects caused by lice infestation reported in Begumganj upazila hospital, Noakhali district, Bangladesh. This is the first case of domestic pigeon recorded in Bangladesh and the aim of this case study is to determine the causal agent, treatment and management procedure of windpuff. Parasitological examination of feathers revealed the presence of Columbicola columbae, a dorso-ventrally flattened biting type louse. Using needle puncture was able to release the ballooning condition and the pigeons were treated with antimicrobial drug (Enrofloxacin @10mg/kg body weight) through drinking water along with multivitamin and ectoparasiticidal drug (Ivermectin @0.4mg/kg body weight). Both the pigeon was successfully recovered without any further complications within four days.
\end{abstract}

Keywords: Windpuff; Domestic pigeon; Biting type louse; Needle puncture

\section{Introduction}

The domesticated pigeons(family Columbidae)in the recent eras domesticated from rock pigeon (Columba livia) are first mentioned in Mesopotamian records over 5,000 years ago[4]and reared for a multitude purposes like message carrying, laboratory birds, sports (racing), cultural and as spiritual symbols [11].The domestic pigeon(Columba livia domesticus) is a medium sized pigeon showing a variety of plumage color with an attractive appearance found in virtually every town and city around the globe [13]. Rearing of pigeon can be considered as backyard poultry farming by the rural people without any investment for providing financial support as well as readily available meat to the household. Being a pet bird and rearing under human control, a variety of ectoparasite infestation especially louse infestation is common in pigeon resulting behavioral changes and decline in egg production [2].Pigeons try to remove lice from their feather by scratching or rubbing with inanimate objects as a result there is a loss of feathers damage of skin leading to a rare condition called windpuff [6] or subcutaneous emphysema. Windpuff is rarely observed in pigeon and occurred by rupturing tissue overlying air sacs through a skin wound or as the result of damage to any part of the respiratory system [14]. When air escapes from the affected air sacs, it fills the subcutaneous space and the skin inflates

\footnotetext{
${ }^{*}$ Corresponding author: Omar Faruk Miazi

Department of Genetics and Animal Breeding, Chittagong Veterinary and Animal Sciences University (CVASU), Chattogram, Bangladesh.
}

Copyright (c) 2021 Author(s) retain the copyright of this article. This article is published under the terms of the Creative Commons Attribution Liscense 4.0. 
around the area. Although this condition is not usually life-threatening but fatal cases can also occur. But the accumulation of gas beneath the skin affects discomfiture, the health of bird's life and specially immunity. This ballooning condition of the pigeon can be effectively treated by removal of air with a syringe and hypodermic needle puncturing resulting decrease in the air volume and tension of the skin. But in many cases, the reduced space will refill quickly as the bird breathes. In those cases, making a fistula by the incision of 2-3mm piece of skin over the ballooning area so that refilling will not occur, but the risk of bacterial infection is frequent. Antimicrobial administration must be suggested to perform this operation to prevent bacterial complications [7, 12]. So far, very few studies [17] have been carried out to alleviated louse infestation followed by windpuff and their treatment. In this case report, windpuff due to Columbicola columbae infestation in domestic pigeon and its therapeutic management was discussed.

\section{Material and methods}

\subsection{Case presentation}

Two 7 months old domestic pigeon (Columba livia) presented to the Upazila Veterinary Hospital, Begumganj, Noakhali district with a history of feather loss, dullness followed by anorexia and gas accumulation beneath the skin in the thoracic and abdominal region for 5 days (Figure 1). Pigeons were reared in the wooden box separately in pairs with proper ventilation and protection from raining water. They were allowed to feed with wheat, maize, paddy, rice, legume and natural sources feed.
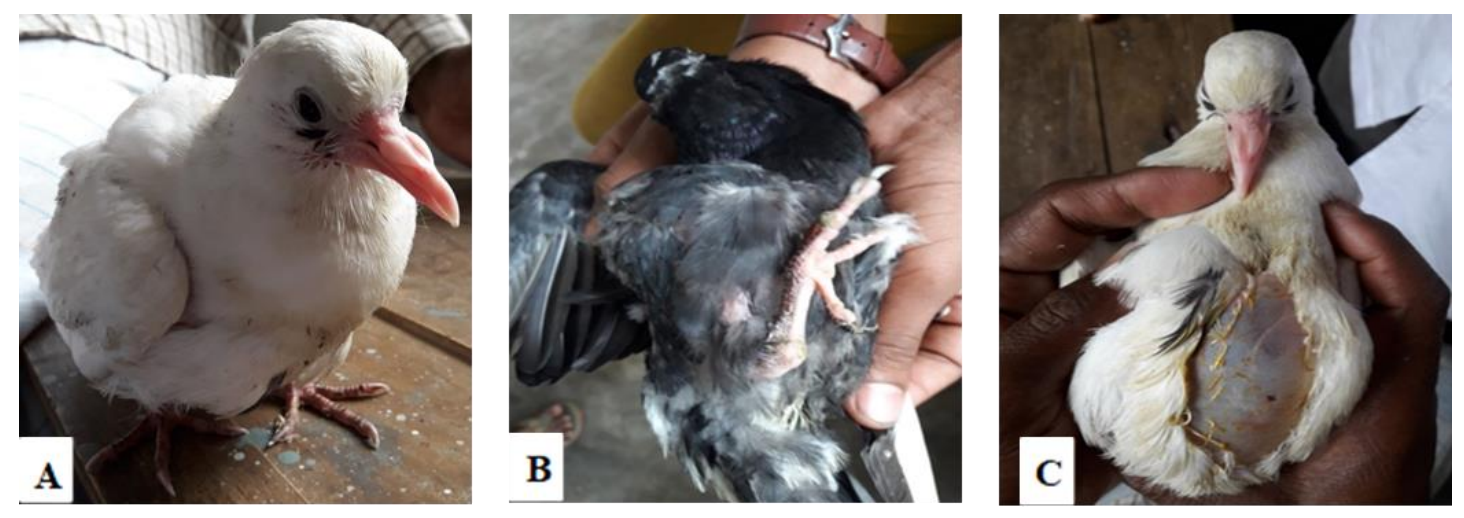

Figure 1 (A) \& (B) Subcutaneous emphysema in domestic pigeon, (C) Feather loss at the ballooning area

\subsection{Clinical examination}

On clinical examination a soft, painless accumulation of air under the skin was observed along with dehydration followed by ruffled feathers. The pigeons were lost their feather at the site of ballooning. Examination of feathers with magnifying glass found the presence of lice all over the body and lice samples were collected for identification. Based on the history and clinical examination two pigeons were tentatively diagnosed as windpuff.

\subsection{Parasitological examination}

Collected lice sample were processed by gentle boiling in $10 \% \mathrm{KOH}$ solution. The samples were washed in tap water after proper boiling and allowed to dry for 15 minutes. After drying the slides were viewed under the 10X magnification under a light microscope for morphological identification.

\subsection{Treatment}

Both the pigeon was restrained carefully by the owner and complete aseptic measures were taken to puncture the ballooning area with caution over the skin and subcutaneous tissues using a sterile $3 \mathrm{ml}$ syringe needle (Figure 2). The accumulated air beneath the skin was removed by squishing out gently. Povidone Iodine solution was administered over the punctured area to avoid any bacterial infection as post-operative treatment and was advised to continue for 3 days. Enrofloxacin solution (Sol. Enflox-vet ${ }^{\circledR}$ ) was prescribed through drinking water @10mg/kg body weight twice daily for 5 days along with multivitamin supplement (Liq. B-com vit ${ }^{\circledR}$ )therapy and ectoparasiticidal Ivermectin solution $@ 0.4 \mathrm{mg} / \mathrm{kg}$ body weight (Sol. Acimec $1 \%{ }^{\circledR}$ ).Both the pigeon were successfully recovered without any further complications within 4 days. 

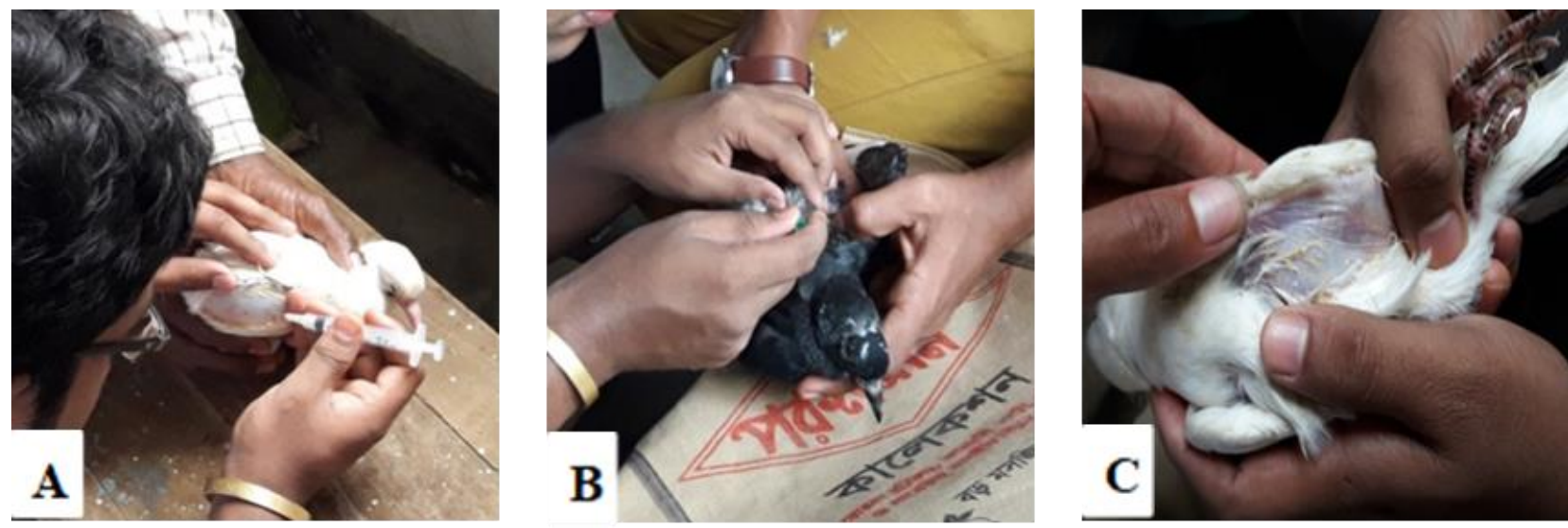

Figure 2 (A) \& (B) Needle puncture using $3 \mathrm{ml}$ syringe in several zones with a sterile hypodermic needle to remove the subcutaneous gas (C) Reduction of the gas and relief of the pigeon

\section{Results and discussion}

The lice sample collected from wing feathers were identified as Columbicola columbae (Figure 3). The louse was 2-3mm in length, dorso-ventrally flattened with an elongated reddish brown head. The characteristic of this louse is the presence of two blade-like hairs called setae and thin antennae with five segments on the anterior portion of its head [16]. Scientist $[1,8]$ reported Columbicola columbae infestation in domestic pigeon is $18.08 \%$ in Rajshahi, Natore and Pabna and $21 \%$ in the Chattogram metropolitan area of Bangladesh. This biting type of lice infestation in pigeon can cause serious illness.

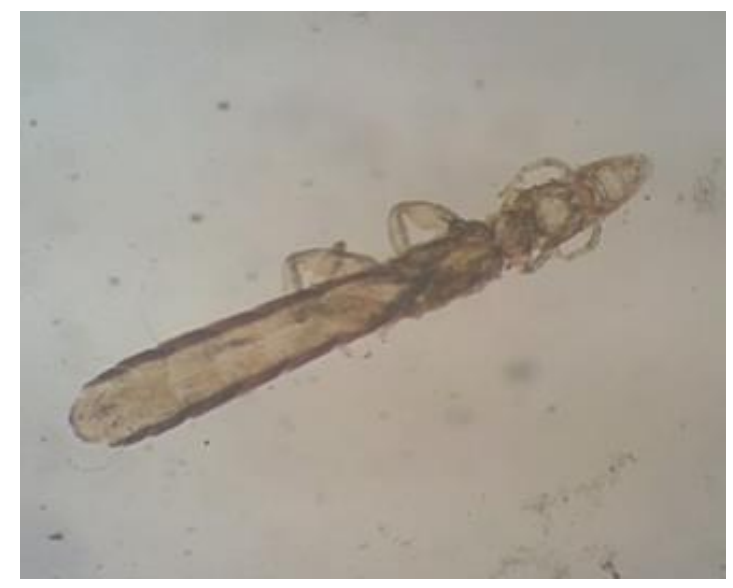

Figure 3 Columbicola columbae under $10 \mathrm{X}$ magnification

Subcutaneous emphysema could be differentiated from other conditions by its features (non-painful, non-feverish, and ballooning appearance on gentle palpation) and easily diagnosed by aspiring with a fine needle [10]. This ballooning condition was differentiated from subcutaneous edema due to the presence of air in lieu of fluid. Trauma, air sac inflammation associated with infection and nutritional deficiencies has been identified as etiological causes of windpuff in birds $[3,18]$. But irritation due to lice infestation and causing subcutaneous emphysema is rare and this is the first case report that occurred in Bangladesh. In India, windpuff due to lice infestation has been reported [17] in Chennai. Besides this many researchers have been reported this case with unknown etiology [5, 12 15]. This ballooning condition could recur, if the gas is removed repetitively without correcting the primary causes [9]. In this case report, trauma due to irritation by lice was the major cause of windpuff based on its history.

\section{Conclusion}

This case report describes the clinical and therapeutic approach of a rare condition of windpuff in domestic pigeon. This case of subcutaneous emphysema as a result of irritation due to pediculosis was diagnosed based on history, physical and parasitological examination. Both the pigeons were examined the regular interval after Ivermectin administration 
on the 0 day and $7^{\text {th }}$ day to ensure the absence of lice in the naked eye. The pigeons were kept in isolation and fed by the owner but after the second day, the bird restarted feeding on its own. The pigeons were recovered with no evidence of windpuff. Attention should be taken when puncturing the skin to circumvent the entry of microorganisms in addition to injury to internal organs.

\section{Compliance with ethical standards}

\section{Acknowledgments}

The authors are grateful to the Upazila Veterinary Hospital, Begumgonj, Noakhali district, Bangladesh.

\section{Disclosure of conflict of interest}

Mishuk Shaha diagnosed and treated this case under the guidance of Ashim Baran Sen. Towhida Kamal performed parasitological examination. Omar Faruk Miazi, Gous Miah and Ashutosh Das involved in supervision. Mishuk Shaha, Arjuman Lima, Sabuj Kanti Nath, Pranab Paul drafted and finalized the manuscript. All authors read and approved the final manuscript.

\section{References}

[1] Akter MTD, Sarder MJU, Islam MH, Islam MR, Parvaz NH, Alam MN. Study on Diseases Prevalence in the Selected Area's Emphasis on Parasitic Diseases of Pigeon. Preprints. 2020.

[2] Alali F, Alhaitami I, Jawad RA, Jawad M. Identification of two new species of chewing lice in pigeon (Columba liviadomestica) in Kerbala Province, Iraq. In AIP Conference Proceedings. 2020; 2290(1): 20-37.

[3] Bennett RA, Harrison GJ. Soft tissue surgery. In: Ritchie BW, Harrison GJ, Harrison LR. Avian Medicine: Principles and Application. Wingers Publishing. 1994; 1096-1136.

[4] Blechman AD. Pigeons: The fascinating saga of the world's most revered and reviled bird. Grove Press, New York. 2007; 4: 50-60.

[5] Choudhury D. A case report on subcutaneous emphysema in Vanaraja Chicken. International Journal of Applied Research. 2020; 6(12): 247-248.

[6] Crespo R. Developmental, metabolic, and other noninfectious disorders. Diseases of Poultry. 2020; $1286-1329$.

[7] Devarathnam J, Naveen M. Subcutaneous emphysema in a pullet. International Journal of Agricultural Sciences and Veterinary Medicine. 2013; 1(1).

[8] Ghosh KK, Islam MS, Sikder S, Das S, Chowdhury S, Alim MA. Prevalence of Ecto and Gastrointestinal Parasitic Infections of Pigeon at Chittagong Metropolitan Area, Bangladesh. The Journal of Advances in Parasitology. 2014; 1(1): 9-11.

[9] Harris JM. Teflon dermal stent for the correction of subcutaneous emphysema. In Proceeding of Association of Avian Veterinarians. 1991; 20-21.

[10] Hillyer EV, Orosz S, Dorrestein GM. Respiratory system. In: Altman RB, Clubb SL, Dorrestein GM, Quesenberry K, edition. Avian Medicine and Surgery. Philadelphia, PA: WB Saunders Company. 1997; 387-411.

[11] Jerolmack C. Animal archeology: domestic pigeons and the nature-culture dialectic. Qualitative Sociology Review. 2007; 3(1): 74-95.

[12] Kaboudi K. A rare case of subcutaneous emphysema in a 28 weeks old rooster. International Journal of Veterinary Sciences and Animal Husbandry. 2019; 4(5): 23-25.

[13] Marques TS, Cuadros MR, Silva JD, Baldo M. Parasites of pigeons (Columba livia) in urban areas of lages, Southern Brazil. Latin American Parasitology. 2007; 62(3-4): 183-187.

[14] Saif YM, Faldy AM, Calnek BW, Beard CW, Swayne DE, Barnes HJ, McDougald LR, Glissin JR. Diseases of Poultry, 11th Edition,Iowa State Press. 2003.

[15] Sankar P, Mohammed PS. Subcutaneous emphysema in a Deshi Chicken-A case report. International Journal for Agro Veterinary and Medical Sciences. 2015; 9(3): 74-76. 
[16] Soulsby EJL. Helminths, arthropods and protozoa of domesticated animals. Seventh edition, Bailliere, Tindall and Cassell. 2012; 367-670.

[17] Sundaram AS, Rajkumar K, Arunkumar S, Gnanaraj PT. Subcutaneous emphysema in a domesticated fantail pigeon caused by Columbicolacolumbae infestation: A case report. Journal of Entomology and Zoology Studies. 2018; 6(4): 983-985.

[18] Tully TN, Harrison GJ. Pneumatology. In: Ritchie, B.W., Harrison, G.J. and Harrison, L.R. Avian Medicine: Principles and Application. Wingers Publishing. 1994; 556-581. 